\title{
Problem confrontation of sugarcane farmers in Natore district of Bangladesh
}

\author{
M.J. Hoque*, M.I. Hossain, M.A. Sarker and M.N.A.S. Mithun \\ Received 30 April 2021, Revised 24 May 2021, Accepted 23 June 2021, Published online 30 June 2021
}

\begin{abstract}
A B S T R A C T
The present study was conducted to explore the problems of sugarcane farmers in the selected areas of Natore district in Bangladesh. A total of 100 farmers were selected from Lalpur upazila of Natore district by using a simple random sampling technique. Data were collected through individual interviews during October to November, 2019 by using a structured interview schedule. Both descriptive and inferential statistics were used to analyze data. The majority of the sugarcane farmers $(80 \%)$ had medium problems in sugarcane cultivation. Among twenty problems, difficulty in getting sugarcane setts was identified as the most critical one, followed by low market price of sugarcane. The least important problem faced by the farmers was lack of labour for sugarcane cultivation. Correlation analysis revealed that credit received, input availability, and extension media contact were significantly associated with the problems of sugarcane farmers. The study indicated some opportunities for the policymakers to address the dominant factors i.e. credit received, input availability, and extension media contact for increasing sugarcane production. Moreover, credit facilities, supply of inputs, proper training and access to extension services could play a vital role in lessening problems in sugarcane cultivation.
\end{abstract}

Keywords: Sugarcane, Farmers, Problems, Bangladesh.

Department of Agricultural Extension Education, Bangladesh Agricultural University, Mymensingh-2202, Bangladesh

*Corresponding author's email: jiaul_agext@bau.edu.bd (M.J. Hoque)

Cite this article as: Hoque, M.J., Hossain, M.I., Sarker, M.A. and Mithun, M.N.A.S. 2021. Problem Confrontation of Sugarcane Farmers in Natore District of Bangladesh. Int. J. Agril. Res. Innov. Tech. 11(1): 101-108. https://doi.org/10.3329/ijarit.v11i1.54472

\section{Introduction}

Sugarcane (Saccharum officinarum) is one of the important agricultural crops in the world (Tukaew et al., 2016). It is an annual commercial field crop grown in tropical and subtropical areas (Khaiyam et al., 2018; Tabriz et al., 2021). Sugarcane is used as a raw material for making sugar, biofuels, bioproducts, and plays a vital role in daily life of any nation including nutritional and economic sustenance (Ambetsa et al., 2020). It contributes $86 \%$ to sugar production as a vital source of white sugar globally (Rumankova and Smutka, 2013; OECD-FAO, 2019).

Sugarcane is the important cash-cum industrial crop and mainly used for producing white sugar in Bangladesh (Rahman et al., 2016; Tabriz et al., 2021). It ranks second among the cash crops and it ranks third among major field crops in the country (Rahman et al., 2016). Sugarcane cultivation covers about $1.2 \%$ of the total agricultural land in Bangladesh (BSRI, 2016). Presently, sugarcane is grown in 0.17 million ha of land of which about 0.086 million ha is located in the sugar mills zones and remaining 0.084 million ha is situated in the non-mill zones (BSRI, 2020). About 5 million people depend on sugarcane cultivation for their livelihood and it contributes $0.81 \%$ to the national economy of Bangladesh (BSRI, 2020).

The sugar production in Bangladesh is quite low but demand of sugar is getting higher day by day due to high growth rate of population (Rahman et al., 2016). The average yield of sugarcane is 45.81 ton $\mathrm{ha}^{-1}$ in Bangladesh which is very much low compared to other cane producing countries (Rahman et al., 2016). The current production of sugar can meet only $25 \%$ of the national demand, while imported sugar satisfies the remaining $75 \%$ of the same (Rahman et al., 2016). Therefore, the yield of sugarcane in Bangladesh needs to be increased to ensure timely supply for the growing population (Tabriz et al., 2021). 
The production of sugarcane is fluctuated from year to year due to various reasons in Bangladesh (Reza et al., 2016). Yield and production could not be increased to the desired level without identifying those problems in production of sugarcane (Hossain and Abdulla, 2015). The main constraints of low production might be traditional farming practices adopted by sugarcane growers (Raza et al., 2020). There may be several problems in producing sugarcane like increased rates of inputs, low return of output, little knowledge of farmers about scientific methods etc. (Nazir et al., 2013). According to Karim et al. (2016), the sugarcane farmers of Bangladesh have been facing a lot of problems like shortage and high wages of labour, high price of inputs, low price of sugarcane/sugar, high insect and pest infestation etc. Investigating those problems and identifying how to overcome them may increase the production of sugarcane in Bangladesh.
Therefore, the present study was conducted to explore the extent of problems faced by the sugarcane farmers in producing sugarcane. The specific objectives were to describe the socioeconomic characteristics of the sugarcane farmers; explore the extent of problems of sugarcane farmers; and determine the relationships between socioeconomic characteristics of sugarcane farmers and their problem confrontation.

\section{Methodology}

\section{Study area}

The study was carried out in Arbab union of Lalpur upazila (sub-district) under Natore district in Bangladesh (Fig. 1). The upazila is located in between $24^{\circ} 07^{\prime}$ and $24^{\circ} 18^{\prime}$ north latitudes and in between $88^{\circ} 52^{\prime}$ and $89^{\circ} 08^{\prime}$ east longitudes. In the study area, a huge number of farmers were engaged in sugarcane cultivation (Reza et al., 2016).

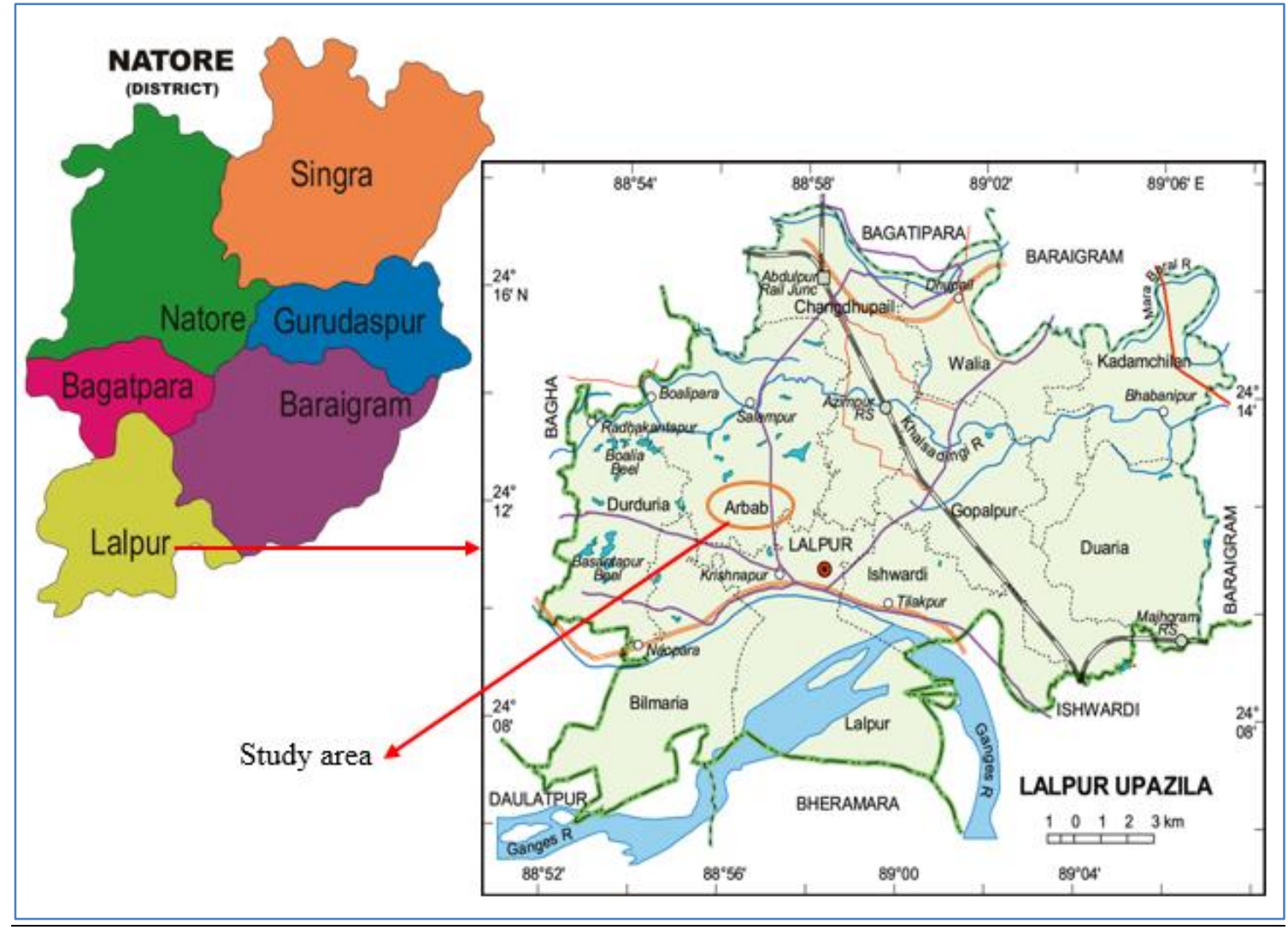

Fig. 1. Map showing the study area.

Population, sampling, data collection and analysis

The farm households involved in sugarcane cultivation were the target population of the study. The farmers were selected by using a simple random sampling technique from Arbab union of Lalpur upazila. The union was selected purposively through the discussion with upazila agriculture officer of Lalpur upazila. A list of farmers growing sugarcane was collected from upazila agriculture office and around 500 farmers were found in the list. A total of 100 farmers (20\% of total population) were selected randomly as sample for the survey. Data were collected through individual interviews during October to November, 2019 by using a structured interview schedule. 
Extent of problems of sugarcane farmers was the focus variable and fourteen socioeconomic characteristics of them were selected as explanatory variables namely age, education, household size, farming experience, farm size, sugarcane cultivation area, sources to sell sugarcane, annual family income, credit received, input availability, organizational participation, extension media contact, training exposure, and knowledge on sugarcane cultivation.

The socioeconomic characteristics of the sugarcane farmers for the study were measured with descriptive statistics viz. mean, standard deviation, and percent. According to Fraenkel et al. (2012), descriptive statistics help to explain the characteristics and basic features of the respondents in a study.

A four-point rating scale was used to explore the extent of problems of sugarcane farmers in the study area (Mithun et al., 2020). A total of twenty (20) problems in sugarcane cultivation were identified from the focus group discussions (FGD) and available literature. Each problem was scored with four possible responses: high, medium, low and not at all, with corresponding scores of 3, 2, 1 and $o$, respectively. Hence, the scale score ranged from $\mathrm{O}$ to 60 , where 60 indicates severe problem, and $\mathrm{o}$ indicates no problem. A problem facing index (PFI) was calculated to measure the extent of severity of the problems faced by the sugarcane farmers in the study area (Equation 1) (Amin et al., 2016; Pandit and Basak, 2013; Uddin et al., 2020).

$P F I=\frac{P_{h} \times 3+P_{m} \times 2+P_{l} \times 1+P_{n} \times 0}{N}$.......

Where,

PFI $=$ problem facing index, $\mathrm{P}_{\mathrm{h}}=$ number of responses with high problems, $\mathrm{P}_{\mathrm{m}}=$ number of responses with medium problems, $\mathrm{P}_{1}=$ number of responses with low problems, $\mathrm{P}_{\mathrm{n}}=$ number of responses with no problem, and $\mathrm{N}=$ total number of responses

The factors associated with problems of sugarcane farmers were measured employing Pearson's product-moment correlation coefficient. For the analysis, the data were cleaned, coded, and analyzed with the statistical package for social sciences (SPSS) var. 20. Microsoft excel 13 was used for preparing different charts and graphs. To explore the relationship between the explanatory variables and focus variable, Pearson's product-moment correlation coefficient (r) (Pearson, 1895) was computed (Equation 2). $r_{x y}=\frac{\sum\left(x_{i}-\bar{x}\right)\left(y_{i}-\bar{y}\right)}{\sqrt{\sum\left(x_{i}-\bar{x}\right)^{2} \sum\left(y_{i}-\bar{y}\right)^{2}}}$

Where,

$r_{x y}=$ Pearson's product-moment correlation coefficient

$\overleftarrow{x}$ and $\bar{y}=$ Means of the variables $x$ and $y$, respectively

\section{Results and Discussion}

\section{Socioeconomic characteristics of the sugarcane farmers}

The socioeconomic characteristics of the sugarcane farmers are presented in Table 1. Findings reveal that the majorities $(80 \%)$ of the farmers were middle to old aged and more than half of them (56\%) could sign their names only. Educated farmers possess more knowledge, more ability to understand and respond to critical situations (Mulinya, 2017; Pandit and Basak, 2013) and therefore, are more likely to face lower problems. Four-fifth of the respondents (80\%) was from small to medium sized household categories. An overwhelming majority of them (85\%) had medium to high farming experience and the highest proportions (88\%) of them had small sized farm (Table 1). Almost all of the respondents (95\%) mainly used their small sized farm area for sugarcane cultivation. Laosutsan et al. (2019) reported that the cultivation area contributed significantly to minimize farm problems. More than four-fifth of the respondent farmers (85\%) were accustomed to sell their harvested sugarcane in the local market and most of them (90\%) had low to medium income.

Results also show that the highest proportions of the respondents (90\%) received no credit facilities and three-fourth of them (75\%) had high level of available inputs for sugarcane cultivation in the study area. Table 1 indicate that more than four-fifth of them (90\%) had no organizational participation and the highest proportions (62\%) of the respondent sugarcane farmers had medium contact with extension personnel. Tey et al. (2014) explained that organizational participation greatly influences the management of agricultural activities. Majority of the respondent sugarcane farmers (92\%) received no training. Ituma and Ukah (2017) asserted that training enhances farmers' ability to manage farms and contribute maximum productivity of the farms effectively. Most of the respondents (70\%) had medium knowledge on sugarcane cultivation in the investigation area. Knowledge plays a significant role on farmers' capability to overcome their problems (Pandit and Basak, 2013). 
Table 1. Socioeconomic characteristics of the farmers $(n=100)$

\begin{tabular}{|c|c|c|c|}
\hline Socioeconomic characteristics & Respondents (\%) & Mean & SD* \\
\hline \multicolumn{4}{|l|}{ Age (year) } \\
\hline Young age (up to 35) & 20 & \multirow{3}{*}{49.61} & \multirow{3}{*}{12.32} \\
\hline Middle age (36-50) & 32 & & \\
\hline Old age (above 50) & 48 & & \\
\hline \multicolumn{4}{|l|}{ Education (year) } \\
\hline Illiterate (o) & 10 & \multirow{5}{*}{2.21} & \multirow{5}{*}{2.92} \\
\hline Sign only (0.5) & 56 & & \\
\hline Primary (1-5) & 17 & & \\
\hline Secondary $(6-10)$ & 15 & & \\
\hline Above secondary (above 10) & 2 & & \\
\hline \multicolumn{4}{|l|}{ Household size (number) } \\
\hline Small (up to 4) & 34 & \multirow{3}{*}{$5 \cdot 31$} & \multirow{3}{*}{1.32} \\
\hline Medium (5-7) & 46 & & \\
\hline Large (above 7) & 20 & & \\
\hline \multicolumn{4}{|l|}{ Farming experience (year) } \\
\hline Low (up to 18 ) & 15 & \multirow{3}{*}{25.85} & \multirow{3}{*}{12.3} \\
\hline Medium (19-36) & 57 & & \\
\hline High (above 36) & 28 & & \\
\hline \multicolumn{4}{|l|}{ Farm size (ha) } \\
\hline Small (up to $1 \mathrm{ha}$ ) & 88 & \multirow{3}{*}{0.47} & \multirow{3}{*}{0.36} \\
\hline Medium (1.01-3 ha) & 12 & & \\
\hline Large (above 3 ha) & 0 & & \\
\hline \multicolumn{4}{|l|}{ Sugarcane cultivation area (ha) } \\
\hline Small (up to 0.5 ha) & 95 & \multirow{3}{*}{0.28} & \multirow{3}{*}{0.23} \\
\hline Medium (o.6-2 ha) & 5 & & \\
\hline Large (above 2 ha) & o & & \\
\hline \multicolumn{4}{|l|}{ Sources to sell sugarcane (place) } \\
\hline Mill (o) & 15 & \multirow{2}{*}{1.15} & \\
\hline Local Market (1) & 85 & & 0.36 \\
\hline Annual family income ('ooo' $\mathrm{B}$ & & & \\
\hline Low (up to 80) & 54 & & \\
\hline Medium $(81-150)$ & 36 & 89.43 & 46.47 \\
\hline High (above 150) & 10 & & \\
\hline Credit received ('ooo' BDT) & & & \\
\hline No credit (o) & 90 & 170 & 85 \\
\hline Credit received (1) & 10 & 1.79 & 8.25 \\
\hline Input availability (score) & & & \\
\hline Low (up to 5 ) & 5 & & \\
\hline Medium (6-11) & 20 & 12.93 & 1.89 \\
\hline High (above 11 ) & 75 & & \\
\hline Organizational participation & & & \\
\hline No participation (o) & 90 & & \\
\hline Participation ( 1 or more) & 10 & 0.18 & 0.47 \\
\hline Extension media contact (scor & & & \\
\hline Low ( up to 13 ) & 33 & & \\
\hline Medium ( 14-27) & 62 & 15.14 & 5.26 \\
\hline High ( above 27) & 5 & & \\
\hline Training exposure (day) & & & \\
\hline No training $(\mathrm{o})$ & 92 & & \\
\hline Training received (1-3) & 8 & 0.1 & 0.38 \\
\hline Knowledge on sugarcane culti & & & \\
\hline Low (up to 13) & 30 & & \\
\hline Medium (14-26) & 70 & 21.69 & 1.72 \\
\hline High (above 26) & 0 & & \\
\hline
\end{tabular}

$S D^{*}=$ Standard Deviation $;$ ha = hectare $; B D T=$ Bangladeshi Taka 
Extent of problems of sugarcane farmers

Findings shown in Fig. 2 present the extent of problems of sugarcane farmers in the study area. Results hint that majority of the respondents (80\%) had medium problems in sugarcane cultivation followed by high problems (20\%). In comparison, no farmer (o\%) reported low problems in sugarcane cultivation in the study area. The findings imply that the sugarcane farmers in the study area had trouble in sugarcane cultivation. Several factors might be responsible for those problems such as low income of the farmers, lack of training facilities, limited organizational participation etc. in the study area (Table 1). The findings are akin to those of Karim et al. (2016) who reported that the highest proportions of the respondents (63\%) faced medium constraints in sugarcane cultivation. Azad et al. (2014) stated that majority of the farmers (79.9\%) perceived medium to high problems in vegetable cultivation in Chuadanga district of Bangladesh. Pandit and Basak (2013), Kabir et al. (2011), Amin et al. (2016) and Uddin et al. (2020) also found similar results in their studies.

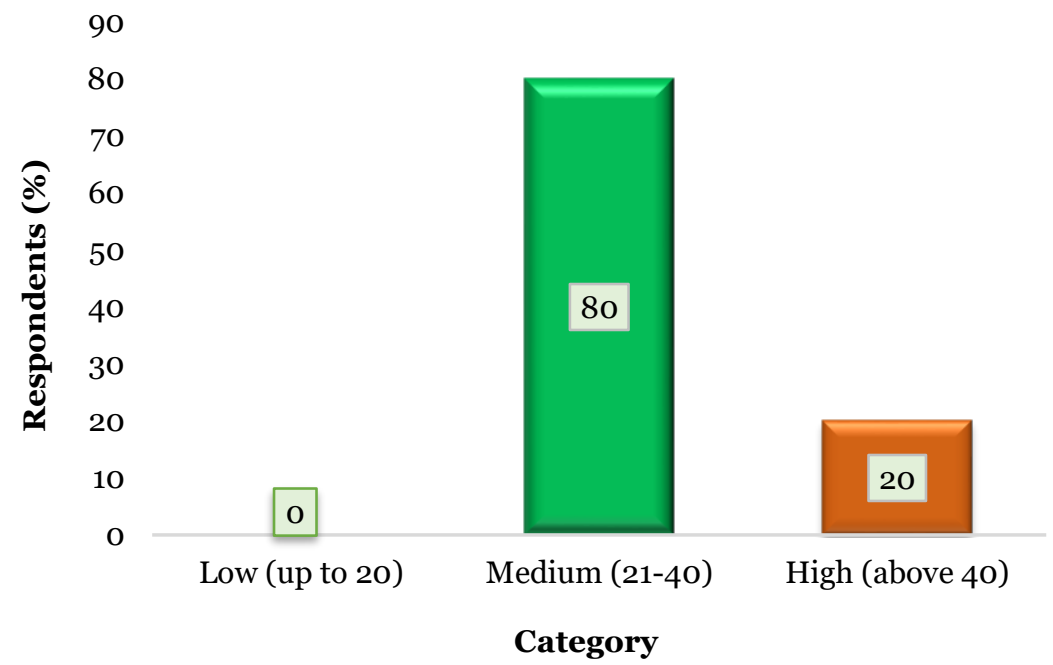

Fig. 2. Extent of problems of sugarcane farmers.

Table 2. Problems of sugarcane farmers $(n=100)$

\begin{tabular}{|l|c|c|c|c|c|c|}
\hline \multicolumn{1}{|c}{ Problems } & High & Medium & Low & $\begin{array}{c}\text { Not } \\
\text { at all }\end{array}$ & PFI & $\begin{array}{c}\text { Rank } \\
\text { Order }\end{array}$ \\
\hline Difficulty in getting sugarcane setts & & & & & & \\
\hline Low market price of sugarcane & 75 & 15 & 5 & 5 & 2.60 & 1 \\
\hline Lack of capital for sugarcane cultivation & 60 & 20 & 10 & 10 & 2.35 & 2 \\
\hline $\begin{array}{l}\text { Lack of modern sugarcane processing } \\
\text { machineries in the sugar mills }\end{array}$ & 55 & 25 & 15 & 5 & 1.75 & 4 \\
\hline Difficulty in getting price from sugar mill & 55 & 20 & 15 & 10 & 1.65 & 5 \\
\hline Lack of high yielding varieties & 20 & 35 & 32 & 13 & 1.62 & 6 \\
\hline Lack of mechanical harvester & 11 & 45 & 30 & 14 & 1.53 & 7 \\
\hline Lack of training facility on sugarcane cultivation & 7 & 50 & 28 & 15 & 1.49 & 8 \\
\hline Drainage problem & 12 & 45 & 17 & 26 & 1.43 & 9 \\
\hline Lack of knowledge on sugarcane maturity & 6 & 40 & 41 & 13 & 1.39 & 10 \\
\hline Lack of transport facilities & 10 & 30 & 40 & 20 & 1.30 & 11 \\
\hline Lack of land preparing machineries & 5 & 45 & 22 & 28 & 1.27 & 12 \\
\hline Lack of disease free setts & 8 & 40 & 20 & 32 & 1.24 & 13 \\
\hline $\begin{array}{l}\text { Facing problem in tying and earthing up of } \\
\text { sugarcane }\end{array}$ & 10 & 33 & 23 & 34 & 1.19 & 14 \\
\hline High price of fertilizers and pesticides & & & & & & \\
\hline Irrigation problem & 5 & 35 & 29 & 31 & 1.14 & 15 \\
\hline Weeding problem & 5 & 25 & 34 & 30 & 1.12 & 16 \\
\hline Lack of knowledge on preparing setts & 12 & 28 & 43 & 27 & 1.08 & 17 \\
\hline Lack of suitable land & 15 & 20 & 35 & 45 & 1.07 & 18 \\
\hline Lack of labor & 10 & 15 & 42 & 33 & 1.05 & 19 \\
\hline
\end{tabular}

PFI = Problem Facing Index; setts = stem cuttings of sugarcane used as propagating material . 
A problem-facing index (PFI) was computed and presented in Table 2 in order to show the extent of individual problems in sugarcane cultivation. The findings indicated that difficulty in getting sugarcane setts was the most important problem of farmers in sugarcane cultivation ( $\mathrm{PFI}=2.60)$. Availability of good quality setts is essential to ensure proper growth and development of the seedlings of sugarcane. The high yielding variety of sugarcane setts increases the overall sugarcane production and makes handsome profit for the farmers. Vishwakarma et al. (2021) found nonavailability and high cost of sugarcane setts for seed as second most significant problem.

Low market price of sugarcane (PFI $=2.35$ ) was the second important problem reported by the respondents. The medium and small farmers in the study area, who faced limited ability to supply sugarcane to the sugar mills, sold their sugarcane with low price in the local market. Karim et al. (2016) observed low price of sugarcane/sugar as the third problem in his study. A study conducted by Pandit and Basak (2013) reported low market price of vegetable during harvesting as the most severe problem in commercial vegetable cultivation.

Lack of capital for sugarcane cultivation with a PFI score of 2.30 was reported as the third important problem in sugarcane cultivation.
According to Singas and Manus (2014), a lack of funds may lead to poor farm management in which farmers are unable to adopt improved technologies for increasing production. Lack of capital was stated as the second crucial constraint by Musaba and Namanwe (2020) and Onyeneke et al. (2020) in their respective studies. However, lack of labour (PFI = 1.02) was the least important problem stated by the sugarcane farmers because there were available labour sources for sugarcane cultivation in the study area. Kabir et al. (2020) found shortage of labor as a least significant problem in his study.

\section{Correlation between socioeconomic characteristics and problems of sugarcane farmers}

Results contained in Table 3 represent the summary of relationship between explanatory and focus variables. Findings indicate that three (3) out of fourteen (14) explanatory variables, i.e. credit received, input availability, and extension media contact showed a negative but significant relationship with the focus variable. Therefore, the results specify that if there would increase in of all the previously mentioned variables there would decrease the level of problems in sugarcane cultivation.

Table 3. Result of correlation analysis between explanatory variables and focus variable.

\begin{tabular}{|c|c|c|}
\hline Focus variable & Explanatory variables & Correlation coefficient (r) with $98 d f$ \\
\hline \multirow{14}{*}{$\begin{array}{l}\text { Problems of } \\
\text { sugarcane } \\
\text { farmers }\end{array}$} & 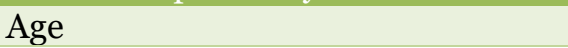 & 0.108 \\
\hline & Education & -0.084 \\
\hline & Household size & 0.186 \\
\hline & Farming experience & 0.096 \\
\hline & Farm size & -0.006 \\
\hline & Sugarcane cultivation area & -0.006 \\
\hline & Sources to sell sugarcane & 0.172 \\
\hline & Annual family income & -0.100 \\
\hline & Credit received & $-0.235^{*}$ \\
\hline & Input availability & $-0.213^{*}$ \\
\hline & Organizational participation & -0.092 \\
\hline & Extension media contact & $-0.372^{* *}$ \\
\hline & Training exposure & 0.119 \\
\hline & Knowledge on sugarcane cultivation & 0.029 \\
\hline
\end{tabular}

** Significant at $1 \%$ level of probability; * Significant at 5\% level of probability.

The results reveal that credit received showed a negative significant relationship $(\mathrm{r}=-0.235)$ with the problems of sugarcane farmers (Table 3 ). Uddin et al. (2020) and Islam (2008) found similar relationship between the concerned variables. The negative significant correlation ( $\mathrm{r}$ $=-0.213$ ) of input availability with the problems of sugarcane farmers clearly pointed out that the farmers with more available inputs (seed, fertilizer, pesticide, insecticide) can minimize the undesirable loss during sugarcane cultivation. An overwhelming majority of the sugarcane farmers (95\%) had medium to high level of available inputs for sugarcane cultivation in the study area (Table 1). Similar relationship was observed by Islam (2008) in his study. Extension media contact had significant and negative relationship $(\mathrm{r}=-0.372)$ with the problems of sugarcane farmers (Table 3), indicate that the farmers with frequent contact with extension media received necessary information on handling of different problems in sugarcane cultivation. According to 
Odini (2014), access to extension personnel renders good sources of information for managing diversified farm activities effectively. A research carried out by Kabir et al. (2020) found that extension media contact contributed significantly to the farmers' problems in Bangladesh. Pandit and Basak (2013) observed similar relationship between extension media contact and constraints faced by the farmers in commercial vegetable cultivation. Amin et al. (2016) reported similar findings in their research.

\section{Conclusions}

Sugarcane farmers in the study area experienced a number of problems, of which, difficulty in getting sugarcane setts, low market price of sugarcane, and lack of capital for sugarcane cultivation were significant. Several factors such as credit received, input availability, and extension media contact of the farmers were found more influential to the problems in sugarcane cultivation. This indicates an opportunity to work on those features to minimize the problems that will make sugarcane cultivation more profitable. Therefore, it is highly recommended that the respective authority may provide better interventions like training, available inputs and extension services to the farmers about sugarcane cultivation that would increase the profitability of sugarcane production. Moreover, different credit organizations (both GOs and NGOs) may come forward with easily accessible credit services to boost up sugarcane production within the study area and other areas with a similar topographical and socioeconomic condition.

\section{Acknowledgements}

The authors express their sincere gratefulness to sugarcane farmers and Department of Agricultural Extension (DAE) of Pabna district in Bangladesh, for providing cherished information.

\section{References}

Ambetsa, F.L., Mwangi, S.C. and Ndirangu, S.N. 2020. Technical efficiency and its determinants in sugarcane production among smallholder sugarcane farmers in Malava sub-county, Kenya. African J. Agric. Res. 15(3): 351-360.

https://doi.org/10.5897/AJAR2020.14703

Amin, M.A., Bashar, M.A., Akhter, N., Afroj, M., Islam, M.Z., Rahman, M.M. and Baque, M.A. 2016. Constraints faced by the farmers in IPM practices in rice cultivation. $J$. Sci. Tech. Environ. 4(1): 245-250.

https://doi.org/10.18801/jstei.040116.27

Azad, M.J., Ali, M.S., Islam, M.R., Yeasmin, M. and Pk, K.H. 2014. Problem Perceived by the Farmers in Vegetable Cultivation. J. Exp. Sci. 5(2): 63-68.
BSRI. 2016. Annual Report 2016. Bangladesh Sugarcrop Research Institute, Ishurdi, Pabna, Bangladesh. pp. 15-20.

BSRI. 2020. Statistics on Sugar Industries of Bangladesh. Bangladesh Sugarcrop Research Institute, Ishurdi, Pabna, Bangladesh. pp. 1-9. Available at: http://www.bsri.gov.bd/site/page/5c95c26f -3655-4dc4-8342-cd3032dc8ba6/ (Accessed on 10 April, 2021)

Fraenkel, J.R., Wallen, N.E. and Hyun, H.H. 2012. How to Design and Evaluate Research in Education. $8^{\text {th }}$ edn. New York: McGrawHill. pp. 75-90.

Hossain, M.M. and Abdulla, F. 2015. Forecasting the Sugarcane Production in Bangladesh by ARIMA Model. J. Stat. Appl. Pro. 4(2): 297303.

Islam, M.R. 2008. Problems Faced by the Farmers in Sugarcane Cultivation. MSc Thesis. Department of Agricultural Extension \& Information System. Sher-EBangla Agricultural University, Dhaka. pp. 52.

Ituma, O.E. and Ukah, N.J. 2017. Training skill needs of secondary school agricultural science graduate in fish farming in Ebonyi state, Nigeria. Int. J. Bus. Manage. Soc. Res. 3: 186-191.

https://doi.org/10.18801/ijbmsr.030217.21

Kabir, K.H., Kashem, M.A. and Miah, M.A.M. 2011. Constraints Faced by the Nursery Owners in the Production of Saplings. Bangladesh J. Ext. Educ. 23(1\&2): 53-60.

Kabir, M.H., Azad, M.J. and Islam, M.N. 2020. Exploring the determinants and constraints of smallholder vegetable farmers' adaptation capacity to climate change: A case of Bogura district, Bangladesh. J. Agric. Crop Res. 8(9): 176-186.

https://doi.org/10.33495/jacr_v8i9.20.159

Karim, S.M.R., Pal, S.K., Afrad, M.S.I., Rahman, M.H. and Miah, M.N.A. 2016. Problems Faced by Farmers in Sugarcane Cultivation under Joypurhat Sugar Mills. Bangladesh J. Sugarcane. 37: 76-82.

Khaiyam, M.O., Islam, M.S., Ganapati, R.K., Uddin, M.J. and Hossain, M.I. 2018. Suitability of Newly Released Sugarcane Varieties in Farmers Field Condition under High Ganges River Floodplain of Bangladesh. Int. J. Plant Biol. Res. 6(2): 1086.

Laosutsan, P., Shivakoti, G.P. and Soni, P. 2019. Factors Influencing the Adoption of Good Agricultural Practices and Export Decision of Thailand's Vegetable Farmers, Int. J. Commons. 13(2): 867-880. https://doi.org/10.5334/ijc.895

Mithun, M.N.A.S., Kowsari, M.S. and Sheheli, S. 2020. Socioeconomic characteristics and constraints of participatory pond fish farmers in Mymensingh district, Bangladesh. Int. J. Agril. Res. Innov. Tech. 10(2): 170-176.

https://doi.org/10.3329/ijarit.v10i2.51591 
Mulinya, C. 2017. Factors affecting small-scale farmers coping strategies to climate change in Kakamega County in Kenya. J. Hum. Soc. Sci. 22: 100-109. https://doi.org/10.9790/0837-220202100109

Musaba, E.C. and Namanwe, E. 2020. Econometric analysis of socio-economic factors affecting smallholder fish production in Kabwe district, Zambia. Int. J. Res. Stud. Agric. Sci. 6: 5-13. https://doi.org/10.20431/2454-6224.0602002

Nazir, A., Jariko, G.A. and Junejo, M.A. 2013. Factors Affecting Sugarcane Production in Pakistan. Pakistan Sugar J. 12(4): 12-14.

Odini, S. 2014. Access to and use of agricultural information by small scale women farmers in support of efforts to attain food security in Vihiga County, Kenya. J. Emerg. Trends Econ. Manag. Sci. 5: 80-86.

OECD-FAO. 2019. OECD-FAO Agricultural Outlook 2019-2028. OECD Publishing, Paris/Food and Agriculture Organization of the United Nations, Rome. pp. 18-25. https://doi.org/10.1787/agr_outlook-2019-en

Onyeneke, R.U., Iruo, F.A. and Eze, C.C. 2020. Employment creation and constraints to fish farming in the Niger Delta region of Nigeria. Int. J. Env. Sci. Nat. Resour. 23: 48-51. https://doi.org/10.19080/IJESNR.2020.23.5561 08

Pandit, J.C. and Basak, N.C. 2013. Constraints faced by the farmers in commercial cultivation of vegetables. J. Bangladesh Agril. Univ. 11(2): 193-198. https://doi.org/10.3329/jbau.v11i2.19893

Pearson, K. 1895. VII. Note on Regression and Inheritance in the Case of Two Parents. Proc. Royal Soc. London. 58 (347-352): 240-242. https://doi.org/10.1098/rspl.1895.0041

Rahman, M.S., Khatun, S. and Rahman, M.K. 2016. Sugarcane and sugar industry in Bangladesh: an overview. Sugar Tech. 18(6): 627-635. https://doi.org/10.1007/s12355-0160489-Z

Raza, H.A., Mulazim, M., Bilal, M., Sajid, H.B., Shafique, M.T., Irfan, M., Saleem, U., Qadir, M.S., Murtaza, A. and Mahmood, M. 2020. Analysis of Sugarcane Cultivation Constraints with Special Focus on Production, Protection, Marketing and Role of Extension Worker. Glob. Acad. J. Agric. Biosci. 2(5): 54-57.

Reza, M.S., Riazi, M.H. and Khan, M.M.H. 2016. Productivity and Profitability of Sugarcane Production in Northern Bangladesh. Indian J. Comm. Manage. Stud. 7(1): 1-9.

Rumankova, L. and Smutka, L. 2013. Global Sugar Market-The Analysis of Factors Influencing Supply and Demand. Acta Univ. Agric. et Silvic. 53(2): 463-472. https://doi.org/10.11118/actaun201361020463

Singas, S. and Manus, P. 2014. Factors influencing adoption of pond fish farming innovations in Potsy of Morobe Province, Papua New Guinea. Uni. J. Agric. Res. 2: 191-197.

Tabriz, S.S., Kader, M.A., Rokonuzzaman, M., Hossen, M. S. and Awal, M.A. 2021. Prospects and challenges of conservation agriculture in Bangladesh for sustainable sugarcane cultivation. Environ. Dev. Sustain. https://doi.org/10.1007/s10668-02101330-2

Tey, Y.S., Li, E., Bruwer, J., Abdullah, A.M., Brindal, M., Radam, A., Ismail, M.M. and Darham, S. 2014. The relative importance of factors influencing the adoption of sustainable agricultural practices: a factor approach for Malaysian vegetable farmers. Sustain. Sci. 9: 17-29. https://doi.org/10.1007/s11625-013-0219-3

Tukaew, S., Datta, A., Shivakoti, G.P. and Jourdain, D. 2016. Production Practices Influenced Yield and Commercial Cane Sugar Level of Contract Sugarcane Farmers in Thailand. Sugar Tech. 18(3): 299-308. https://doi.org/10.1007/s12355-015-0403-0

Uddin, M.N., Kabir, K.H., Roy, D., Hasan, M.T., Sarker, M.A. and Dunn, E.S. 2020. Understanding the constraints and its related factors in tilapia (Oreochromis sp.) fish culture at farm level: A case from Bangladesh. Aqua. 530: 735927. https://doi.org/10.1016/j.aquaculture.2020.7359 27

Vishwakarma, N., Sangode, P.K. and Khan, M.A. 2021. Problems faced by the sugarcane growers and suggestions given to improve the adoption of recommended sugarcane production technology. J. Pharmacogn. Phytochem. 10(1): 643-645. 